Within the third group are several species including the bivalves Bentharca nodulosa (Müller), Limopsis aurita (Brocchi) and the gastropod Solariella amabilis (Jeffreys). Their presence in this region may be temperature controlled, as they are shelf species in northern Norway whereas in the Bay of Biscay they are found on the middle of the continental slope. Other species present at the shelf break are perhaps near the southern limit of their range and are restricted to the shelf break on the eastern margin of the Faeroe-Shetland Channel. Species in this group include the bivalve Chlamys sulcata (Müller) and the gastropod Troschelia berniciencis (King). A number of rare species are present at the shelf break. These include the gastropods Metzgeria gagei Bouchet and Volutomitra groenlandica (Beck) and the coral Stenocyathus vermiformis (Pourtalès). The records of Stenocyathus and Volutomitra are the first live records in U.K. waters. A feature of the shelf break in this region is the extensive development of iceberg plough marks. Samples dredged from the shelf break have a very distinctive appearance and consist of poorly sorted collections of small boulders, cobbles, pebbles, gravel and sand. Observations of the shelf break and upper slope using the Mark III Television and Camera Sledge confirm the highly variable nature of the sediments present.

The regular echinoid Cidaris cidaris (Linnaeus) and the bivalve Astarte sulcata (da Costa) are very common in these poorly sorted gravels and their presence together is very characteristic of the shelf break. In some parts the poorly sorted gravels give way to more sandy sediments which support species such as the gastropods Typhlomangelia nivalis (Loven) and Cylichna alba (Brown).

Dead shells of species living in the area during the period of low sea level preceding the Flandrian transgression such as the bivalve Chlamys islandicus (Müller) and less commonly Mya truncata (Linnaeus) are also present.

\title{
Aspects of the zoogeography of some benthic animals in the Rockall Trough
}

\author{
G. L. J. Paterson
}

Department of Zoology, British Museum (Natural History), Cromwell Road, London SW7 5BD, U.K.

Distributions of certain benthic species in the Rockall Trough are compared to other regions of the Northeast Atlantic. A numerical cladistic package has been applied to classify the distributions of deep-sea (>500 $\mathrm{m}$ depth) brittle star fauna. Rockall is compared with the Labrador and Southwest Iceland basins, the Iceland Basin, the Bay of Biscay and the Canary region including the Azores, Madeira and N. Africa. Figure $1 \mathrm{~A}$ indicates that the Rockall Trough fauna has a greater affinity to the Biscay and Canary regions than the other two northerly basins. These results are consistent with an hypothesis of an impoverishment of the northern basins, possibly related to the effects of the last Ice Age. 

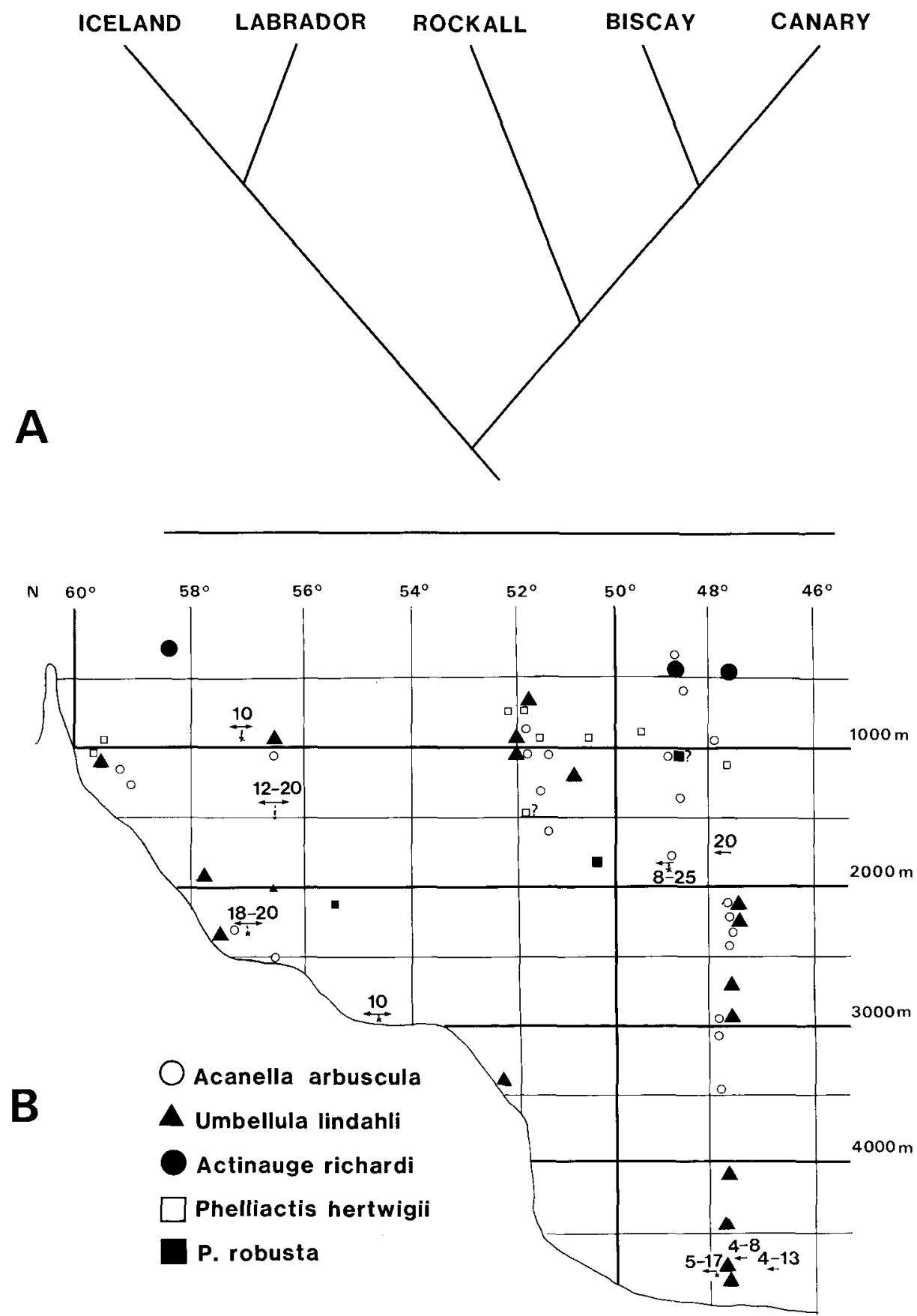

Figure 1. Distributions of deep-sea fauna. A. Cladogram showing the faunal affinities of the northeast Atlantic basins as indicated by analyses of samples of deep-sea brittle stars. B. A strip analysis of the eastern flank of the Rockall Trough showing the distribution of selected coelenterates. Arrows represent current flow and direction, the number associated with the arrow being the recorded current velocity in $\mathrm{cm} / \mathrm{s}$. 
Distributions of sessile suspension feeding echinoderms and coelenterates are considered in the light of the physical environment, particularly bottom currents. The method employed uses a graphical approach which is termed Strip or Profile Analysis. The continental margin can be regarded as a strip where depth is the vertical component and latitude the horizontal. This method is effective at assessing latitudinal variation in distribution. Figure 1B attempts to correlate distributions with physical factors such as water movement and temperature. While some trends are indicated there were not enough data to allow more than a superficial treatment. Nevertheless, the records of suspension feeders indicate areas of persistent water movement which might be useful to physical oceanographers. 